\title{
THE FATE OF THE FIVE-CENT FARE
}

\section{SERVICE-AT-COST IN BOSTON}

\author{
BY T. DAVID ZUKERMAN \\ New York Bureau of Municipal Research
}

\begin{abstract}
As a side-light on the New York City traction problem, the Bureau of Municipal Research carefully reviewed and here presents the Boston experience with public operation combined with private ownership.
\end{abstract}

The electric railway industry is today the "sick man of business." It has come out of the war in much worse shape than other staple industries and is still facing a crisis. A material portion of the street railway milcage of the country is in the hands of receivers; not a little has been abandoned and sold for junk; and both processes are being continued. 'That the situation is no worse than it actually is can be ascribed to the mildness of the winter through which we have just passed as well as to the ending of the war.

\section{DIFFICULTY OF MEETING TRACTION PROBLEM}

The traction managers and investors are clearly at a loss as to the solution for the problems they are facing. When the need for additional revenues became insistent, apparently the one method of meeting it that appealed to the traction interests was an increase in fares. The evils of the industry were attributed to the fixed price at which transportation was being supplied. Now, however, that the companies operating in nearly four hundred communities throughout the country have been granted increases in farein many cases two or three timesranging from 20 per cent to 100 per cent, it is becoming more and more evident that the fare increase in itself is not a panacea for the ills from which the street railways are suffering. The results are distinctly disappointing. That such is the case is frankly admitted by prominent traction managers and financiers.

\section{SERVICE-AT-COST FRANCHISE THE PRO- POSED SOLUTION}

The last hope of railway men for private ownership and management seems to be the service-at-cost franchise, which furnishes that public cooperation which they now confess is vitally necessary for successful operation. Service-at-cost franchises have been granted in various forms during the past year in Dallas, Texas; Philadelphia, Pennsylvania; Montreal, Canada; Chicago, Illinois; and Cincinnati, Ohio. The legislature of Massachusetts has taken the most radical steps to find a solution for the situation by passing a general service-at-cost act of which any company in the state may avail itself. 'That body went much further, however, in the case of the Boston Elevated Railway Company, which serves the metropolitan area of Boston. The Boston Elevated Act, passed in 1918, provides not only for automatic adjustments in the rate of fare to furnish the revenues necessary to cover all legitimate operating costs, including adequate main- 
tenance and depreciation and a guaranteed dividend; it also provides for payment by the state of any deficits that may nevertheless be incurred.

Traction officials have since been casting envious glances at Boston. They listened with intense interest to Mr. Homer Loring, at present one of the public trustees of the reorganized Bay State system, when, at a conference of the American Electric Railway Association on November 1, 1918, he described the "methods used in Massachusetts" to overcome the opposition to such legislation. 'They are exerting pressure to secure similar consideration for themselves. On the other hand, it is said that the mayor of New York City entered into negotiations with the president of the Interborough Rapid Transit Company with a view to handling that city's traction problem in like fashion in the public interest.

Accordingly there is much of value to be gained from a study of Boston's experience. The situation in that city, since the Boston Elevated Act took effect, illustrates forcibly the difficulties faced in any effort to solve the problem of furnishing transportation under present conditions.

\section{BOSTON TRANSIT PROBLEM CONSIDERED}

IN A SERIES OF INVESTIGATIONS

The troubles of the Boston Elevated were but intensified by war conditions. The company was facing financial difficulties even before the outbreak of the war. The situation became so acute in 1913 that the Boston transit commission and the state public service commission sat as a joint board to consider the company's affairs. Again in 1914, the public service commission made a complete investigation at the request of the legislature.

${ }^{1}$ His paper was printed in full in the Novemker issue of Aera.

\section{SPECIAL COMMISSION OF 1916}

Two years later the directors appealed to the governor of Massachusetts for a special commission of inquiry to suggest possible legislative remedies for the difficulties confronting the company. Reaffirming their belief that the fare charged was inadequate, they insisted on the necessity for a radical increase in revenue. The governor transmitted the appeal to the legislature which complied with the request. In accordance with the suggestion of the directors the special commission appointed included the members of the Boston transit commission and the public service commission, all of whom were familiar with the local problem.

The report of this special commission, submitted to the next legislature, showed that the situation, whatever the causes, was clearly one calling for definite action "even if viewed solely from the standpoint of public necessity. The present stoppage of new capital will, unless the impediments are in some way removed, create at no distant date intolerable transportation conditions within the metropolitan district."

To provide the company with capital for its needs, the commission recommended the purchase by the state of the Cambridge subway, the only tunnel privately owned, involving $\$ 9,000,000$, the return of the $\$ 500,000$ deposited when the company's charter was granted, and the sale of property unused or unfit for transportation purposes. It was further recommended, in order to reduce the company's expenses, that subway rentals be imposed gradually or temporarily capitalized in order that the entire burden should not be felt until the traffic was sufficient to permit payment in full, that similar capitalization of replacements be permitted, and that 
prepayment areas be established to prevent transfer abuses. A more radical proposal was the abolition of the "Compensation Tax" of seven-eighths of one per cent on gross earnings, imposed by the company's charter.

As an alternative to a fare increase in any form, which was considered difficult and impractical, the commission suggested the temporary remission or loan to the company of as much of the general taxes and corporate franchise tax as might be necessary to permit the payment of dividends. Throwing the burden on the taxpayer in that way was justified on the ground that others than the riders benefited from transportation facilities.

Acting on the report of the special commission, the legislature adopted a measure to effect practically all the specific recommendations except the purchase of the Cambridge subway, which the governor opposed on the ground that it might serve as a precedent for numerous requests upon the state government to provide transportation facilities elsewhere. As the most urgent recommendation called for a thorough investigation into the affairs of the Boston Elevated Railway Company, $\$ 15,000$ was made available to the public service commission, which engaged an expert for the purpose.

\section{INVESTIGATION BY PUBLIC SERVICE} COMMISSION IN 1917

The results of this inquiry were made public in a report presented to the legislature early in 1918. This report was supplementary to that of the special commission and its findings were practically similar. It stated that the company had been honestly capitalized and managed. The dividends had always been moderate--in fact even more moderate than was apparent because of the cash premiums paid on most of the securities issued. The difficulties of the company were attributed to wage increases, rising costs of materials and the heavy capital burdens imposed by the subway rentals. As a result the operating expenses and fixed charges during 1916 and 1917 had been increasing faster than the gross income, and the tendency was becoming even more marked. That the situation was no worse was attributed to the savings resulting from the abolition of the "Compensation Tax" and the decrease in the corporate franchise tax due to the lessened market value of the capital stock.

The analysis of the expert, summarized in the commission's report, showed that the general condition of the surface lines was very bad. The company had been "nursing" poor track; equipment and rolling stock were obsolete and ont of repair. Except for the power stations and apparatus, which on the whole were in excellent condition, the property of the company was unsuited for present railway use, being "inheritances from horse-car days." Depreciation reserves were insufficient. In 1916, for example, the company had spent or set aside only one-third as much as was actually necessary for this purpose.

Operation, consequently, was thoroughly wasteful. The expense caused by delays and repairs due to frequent breakdowns of the faulty equipment was great. The cost of superintendence was excessive. So, likewise, was the cost of running surface cars in expensive tunnels on which the overhead alone amounted to as much as 79.6 per cent. It was estimated that a large annual saving could be secured from efficient operation.

To prevent the situation from becoming worse a thorough rehabilitation was absolutely necessary. Renewals neglected in the past would have to be made and all abandoned properties charged off the accounts. An average 
of $\$ 2,750,000$ annually for five years would be required to place roadbed and track in good condition and to substitute modern equipment, improved shops and carhouses.

\section{PUBLIC CONTROL RECOMMANDED}

The commission held that it was imperative to take immediate steps to secure the essential transportation facilities and service at as small a financial burden as possible. Because of the exigencics of war it was believed that "private credit cannot be relied upon to achieve results." There was vital necessity for placing public credit, at least temporarily, solidly behind the system. Accordingly a plan was proposed providing for direct control by trustees representing the public. At the same time what were considered the advantages of private ownership were retained and the situation left in such form that at any time in the future the former status might be recovered without difficulty if such a course seemed desirable.

\section{PROVISIONS OF THE BOSTON ELEVATED $A C ' T$}

The recommendations of the commission were embodied in the Boston Elevated Act ${ }^{2}$ mentioned at the opening of this article. The immediate result of its enactment was an increase in the price of the common stock from $\$ 27$ to $\$ 75$ per share. It provides for

1. Appointment by the governor of five trustees to serve as the board of directors of the company for ten years and to operate the lines owned and leased.

2. Repeal of the clause in the company's charter limiting the fare to five cents. The

${ }_{2}$ "An act to provide for the public operation of the Boston Elevated Railway Co." chapter 159 of Special Acts of 1918. Fnacted and approved $M$ ay 22, 1918. trustees are empowered, without recourse to the public service commission, to fix fares which in their judgment will produce sufficient revenue to meet the "cost of service." This is defined as including operating expenses, taxes, rentals, interest on all indebtedness, sufficient allowances for depreciation, obsolescence and losses on property sold, destroyed or abandoned, all other legitimate charges against income, dividends on preferred stock issued under the act, and a guaranteed dividend on common stock which was fixed at 5 per cent for the first two years and 6 per cent thereafter during the period of public management.

3. Provision of a $\$ 1,000,000$ reserve fund, the condition of which would indicate the need for an increase or decrease in the fare charged, to meet deficiencies in income from operation. Any deficiencies incurred which cannot be met from this reserve fund must be made up by the state and apportioned among the communities served by the railway in proportion to the number of persons using the service.

4. Subscription by the stockholders to an issue of $\$ 3,000,000$ preferred stock with cumulative preferred dividends at not less than par. Of this sum $\$ 1,000,000$ was intended for the abovementioned reserve fund, and the other $\$ 2,000,000$ for additions and betterments to the property.

5. Public operation indefinitely after the tenyear period upon the same terms, until the state elects to discontinue such management and operation by legislation passed not less than two years in advance of the date of termination. The property must be maintained in good operating condition, depreciation, obsolescence, and rehabilitation provided, and the reserve fund kept at full strength if and when control reverts to the stockholders. In such event, furthermore, the company must be permitted to collect "such just and reasonable fares as will produce an income sufficient to pay the reasonable cost of service" as defined above including not more than 6 per cent dividends on the common stock. However, the state will not guarantee the defcits that may be incurred after the period of public control; and although the company will again be subject to supervision by the public service commission, regulation must not be such as to reduce the income below the reasonable cost of service.

6. Acceptance of the act by the stockholders to constitute an agreement to sell the company's assets in full to the state at any time during the period of public management for a payment 
equal to the actual cash paid in by the stockholders on the stock outstanding and the assumption of all indebtedness.

The recommendation for the purchase by the Commonwealth of the Cambridge subway from the company in order to provide capital for future requirements at a low cost was renewed, but not acted upon. A bill is now before the legislature authorizing the public service commission to make an appraisal of this tunnel with a view to such purchase.

The stockholders accepted the bill and subscribed for the required amount of preferred stock. The governor appointed the trustees, who organized and assumed possession and management on July 1, when the bill went into effect.

\section{OPERATING EXPENSES GREATLY INCREASED}

During July several statements indicating the necessity for prompt action were issued by the trustees. Attention was directed to the fact that a deficit of $\$ 579,276$ had been incurred during the first six months of 1918 with operation on a five-cent fare, and that the situation was becoming more serious because expenses were fast increasing. A wage award was pending before the War Labor Board which amounted to about $\$ 3,000,000$ annually. The increased cost of coal is $\$ 500,000$. The new Dorchester subway was opened, necessitating a payment of approximately $\$ 450,000$ annually as rental. Furthermore the requirements of the act called for an additional annual expenditure of $\$ 1,600,000$ for depreciation and $\$ 1,360,000$ for interest and dividends on the new issues of stock and bonds, including the guaranteed dividend on the common stock. In all, the trustees were confronted with new expenses totalling $\$ 7,500,000$ annually which had to be included in the "cost of service."

\section{SEVEN-CRNT FARE ESTABLISHED}

To meet these new expenses, which increased the previous year's costs of operation by 40 per cent, the trustees established a seven-cent fare beginning August 1. They asked for patience and co-operation on the part of the public, and announced that considerable new equipment had been ordered for the purpose of improving the service.

There was apparently little opposition. The public, it was thought, would have as much faith in the trustees as in their other public officials - faith as to the needs and purpose of the increase. Indeed, the results of the first two weelss of operation with seven-cent fares seemed to indicate that the people were satisfied. The revenues increased 30 per cent above the revenues of the corresponding period of the previons year. In comparison with the experience of other electric railways in Massachusetts and elsewhere, this was a remarkable showing.

\section{DEFICITS DESPITE INCREASED FARES}

Even 30 per cent increase, however, was insufficient to meet the full needs for additional revenue. What is more, further experience proved that the psychology of the people in metropolitan Boston differs little from that of people elsewhere. The traffic decreased so sharply that for the full month of August the revenue increase was reduced to 23.79 per cent and there was a deficit for that month of more than $\$ 500,000$. During the next two months the results were worse, and the deficits even larger because of the influenza epidemic, which affected Boston seriously. The November re- 
sults approximated those of August, as can be seen by the following table:

\begin{tabular}{|c|c|c|c|}
\hline & Revenue & Passenger & \\
\hline & Increase & Decrease & Deficit \\
\hline Aug & $.23 .79 \%$ & $11.49 \%$ & $\$ 511,749$ \\
\hline September. . & .12 .09 & 20.02 & 604,999 \\
\hline October. & 2.91 & 26.48 & 799,522 \\
\hline November. & .21 .03 & 13.64 & 500,334 \\
\hline & & & \\
\hline
\end{tabular}

For the four months under sevencent fares, the revenues had increased only 15.82 per cent, and there was a decrease of $21,972,995$ in the number of passengers carried. The deficit, in spite of the fare increase, was $\$ 2,416$,604 which, with the deficit of $\$ 707,959$ incurred in July under the five-cent fare, amounted to $\$ 3,124,563$.

\section{REVENUES FROM EIGHT-CENT FARES ALSO INSUFICIENT}

The results from the seven-cent fare were so disappointing that it was evident early in October that an additional increase was necessary under the law. Hence an eight-cent fare was announced beginning December 1 .

One of the trustees expressed the opinion that because of the epidemic the seven-cent fare had not been given a fair trial. The Boston News Bureau of December 3, however, in a long review of the situation headed "God Save the Commonwealth," insisted that the only honest thing to do was to increase the fare to ten cents. The writer held that only such a rate could net the 50 per cent increase in revenues required. Even if the eight-cent fare should cause no further shrinkage in riding, it would not furnish sufficient revenues to meet the "cost of service" by nearly $\$ 2,000,000$ for the balance of the fiscal year. As a further loss of traffe was certain, the deficit to be expected would probably be greater, indicating a deficit of more than $\$ 5,500,000$ for the first year of public operation in spite of greatly increased fares.

The financial results from operation since November are shown in the following table:

\begin{tabular}{|c|c|c|c|}
\hline & $\begin{array}{l}\text { Revenue } \\
\text { Increase }\end{array}$ & $\begin{array}{l}\text { Cost of Sero } \\
\text { ice per } \\
\text { Passenger }\end{array}$ & Deficit \\
\hline & $36.28 \%$ & $8.778 \mathrm{c}$ & $\$ 149,9$ \\
\hline 919. & & 8.97 & 219,6 \\
\hline February...... & 44.85 & 9.034 & 285,124 \\
\hline March. & $\ldots$ & 8.923 & 224,920 \\
\hline
\end{tabular}

Just how to interpret the above figures so as to indicate the relationship between fare increases and revenue increases is not entirely clear. The year 1918 showed a general falling off in traffic almost everywhere even under the five-cent fare. The first six months of 1918 on the Boston Elevated showed a loss of 2.39 per cent in traffic over the corresponding six months of 1917 and the revenues for July were 2.89 per cent less than those of July 1917. It is evident that war conditions not only prevented the usual traffic increase due to the normal growth of population and development of the community, but that the influenza epidemic also restricted riding and rendered difficult any interpretation of traffic statisties. Normal conditions returning with the ending of the war, however, and the mildness of the winter through which we have just passed, especially as compared with the extremely severe weather of the previous winter, should have helped to secure extremely favorable results since December. Apparently, then, the situation is becoming worse rather than better.

\section{TRUSTEES AST FREE USE OF CITY- OWNED SUBWAYS}

In their report covering the first six months of public operation, the trustees suggested that the company be relieved of the necessity of paying rent 
to the city of Boston for the use of the subways. They said: "One of the features of the street railway situation in Boston which is always noted by visitors acquainted with street railways elsewhere, is the extraordinary burden of subway rentals to be met from operating receipts. The trustees believe that to prevent deficits and eventually to secure a lower fare, it is essential that at least while the public is operating its own railway this charge to operating expense should be removed. The subways and tunnels are public highways built for general public convenience in order to prevent congestion on the surface of streets. No other form of travel or transportation pays through a special tax or assessment the cost of public highways."

This suggestion, however, was strongly opposed by the committee chosen by Mayor Peters to investigate financial questions associated with the operation of the Boston Elevated. This committee recommended, on the other hand, in view of the fact that the company had failed to provide sufficient for depreciation in the past, that dividends be reduced or eliminated entirely until operation showed profits instead of deficits.

\section{ZONE SYSTEM PLANNED}

From the start the trustees asserted the belief that it would be more equitable to devise some other method than a flat increase in the unit fare to secure additional revenue from operation. This belief was intensified when the ineffectiveness of such increase was apparent. Accordingly they engaged Professor Albert S. Richey and Peter Witt, former traction commissioner of Cleveland, to make independent studies of conditions and report on various possible zoning systems of fare collection.

Mr. Witt recommended one-cent zones to attract short-haul traffic and to compel each passenger to pay for the cost of his ride. Professor Richey, however, recommended three plans, all based upon the establishment of a central zone and an outer zone with fare units that would furnish revenue equivalent to that from seven, eight, or ten cent flat fares. He maintained that any system based upon the fivecent unit would not produce sufficient revenue. The chief advantage of the two-zone plan he recommended was the possibility of operating with the minimum of inconvenience in fare collection by the use of the pay-enter and pay-leave method. He also suggested studies of the feasibility of short routes with special low fares in the central business district to build up shorthaul traffic as a convenience to the public and a producer of revenue.

To provoke discussion and test public sentiment on the subject, the trustees advocated the trial of a zone system based on Professor Richey's plan. This proposal was opposed in some quarters on the grounds that it would tend to cause congestion in the inner zone and make fare collections unduly costly and inconvenient. The trustees, however, were not convinced that the advantages did not outweigh the disadvantages. They accordingly announced the establishment beginning April 1 of a two-zone system with a five-cent fare in each zone.

At a legislative conference on February 21, Mr. James F. Jackson, the chairman of the trustees, argued that a zone system seemed to offer a way out of the difficulty and should be given a trial. He insisted that otherwise a nine-cent or a ten-cent fare would be inevitable, and the latter probable. Even if the company were to be relieved from the payment of the subway rentals, the lowest fare possible would be eight cents. A zone system would make possible a larger percentage of 
collections by preventing the present leakage due to dishonest conductors and some of the traveling public.

\section{ZONING POSTPONED BECAUSE OF PRO- POSED LEGISLATION}

Nevertheless, a bill ${ }^{3}$ was introduced in the lower house of the legislature to prevent the trustees from carrying out the plan to establish zoning in Boston. Another bill ${ }^{4}$ was introduced in the senate to amend the Boston Elevated Act by compelling the return to the flat unit fare of five cents, the state to guarantec deficits from operation as before. In spite of the fact that constitutional amendment ratified last November prohibits the state from lending its credit to private corporations, the supreme court of Massachusetts has affirmed the constitutionality of this bill if passed. Both bills are in the hands of committees at the present writing. ${ }^{5}$

Under the circumstances, the trustees withdrew temporarily their plans for a zoning system, especially as its introduction would necessitate an expenditure of $\$ 100,000$. In the meantime the fare remains at eight cents. A large number of former riders now walk and the jitney is becoming increasingly popular in the metropolitan district.

\section{EMPLOYES TO DEMAND INCREASED WAGES}

The situation is further complicated by the termination on May 1 of the wage contract with the employes' union. It is said that the wages committee has formulated and will present demands calling for the establishment

${ }^{3}$ House bill No. 1467.

${ }^{4}$ Senate bill No. 54.

${ }^{5}$ The bill to prohibit zoning has since been voted down. The trustees will probably carry out their plans to establish such a fare scheme. of an eight-hour day and marked increases in wages. Any concessions which may be made will entail additional expense to the company and further increase operating costs.

PUBLICITY INEFFECTIVE TO OVERCOME OPPOSITION TO FARE INCREASE

Such has been Boston's experience with increased fares under the serviceat-cost franchise. The widest publicity was given to the situation. The propaganda that secured the passage of the Boston Elevated Act was continued to ensure its successful operation. The trustees issued numerous statements taking the public into their confidence by showing them the exact state of affairs. Both the trustees and the mayor repeatedly warned the people that if the money was not forthcoming from fares, it would have to be secured by taxation. The traffic, nevertheless, fell off.

It is true that the majority of riders were willing, or compelled by necessity, to pay the increase. The financial stability of the electric railways, however, depends not on those who ride from necessity or who do not object to a higher fare than five cents. It depends rather upon the short-haul passenger who rides for convenience but walks when reminded of the cost. When fares are raised these elements of the population either move nearer to their work or encourage jitney competition. The jitney is always strengthened as a competitor where traction fares are increased. This is happening in metropolitan Boston. Its significance ought not to be underestimated.

\section{EXPERIENCE OF BAY STATE SYSTEM}

The Bay State Street Railway Company, also in Massachusetts, received four increases of fare in various forms in two years since October 1, 
1916. The net result was only onethird the expected increase in revenues after all estimates had been made for shrinkage in traffic. Many parts of the system failed to earn operating expenses. The company recently received a fifth substantial increase of fare pending reorganization, during which the capitalization is being sealed down by $\$ 20,000,000$. The company will operate under a service-at-cost franchise somewhat similar to the Boston Elevated Act. Fares are to be fixed at five cents. Deficits incurred will be divided evenly between the general taxpayer and the car riders.

\section{OPINTON OF MASSACHUSETTS PUBLIC SERVICE COMMISSION}

These experiences are merely parallel to that of the other Massachusetts companies. That state has been more liberal in its treatment of the railways than any other part of the country. In the language of the public service commission, "No one can truthfully say that the raising of rates has not had a fair trial in Massachusetts. The six-cent fare originated here in 1905 , and of late all manner of rates have been introduced. . . . The result has not been what was hoped. With all their raising of fares, our companies seem little nearer financial salvation." 6

In a report to the legislature on the general situation in Massachusetts, under date of February 15, 1919, the commission made this pertinent comment:

The present system, which throws the entire cost of service upon the car riders, apparently rests upon the assumption that the individual riders are the only persons who have any legitimate interest in the maintenance of good local transportation facilities. The fallacy in such an assumption is so obvious that it scarcely needs to be pointed out. In addition to the benefits

6 Sixth Annual report, January 1919. received by individual electric railway patrons, there is a very large community benefit which can be measured by the losses in industry, trade, real estate values and other forms of community wealth which would result if all elcctric railway facilities were suddenly blotted out.

For this benefit, up to the present time, the community has paid nothing and has succeeded not only in unloading its legitimate part of the transportation burden upon the shoulders of the car rider, but also in making him pay, in addition, a portion of the cost of general municipal improvements through the imposition of special taxes and public charges. The only justification for the existing system is the fact that the burden is so widely distributed that fares in the past have bcen relatively low and thcir payment has involved no special hardship.

But when the car riders are compelled, as a large proportion of them now are through reductions in fare zones and increases in the unit of fare, to pay increased fare varying from 100 per cent to 400 per cent, the inequality of the per cent system is thrown into strong relief. The burden is one that the car rider not only ought not to pay but, to speak broadly, cannot pay under present economic conditions.

Accordingly, the commission faces the issue squarely and takes the dennite position that public ownership and operation is the only final solution.

Inasmuch as transportation is necessary to prevent congestion, maintain good living conditions, and to develop the outlying districts, the commission insists that the street railways are a public necessity just as the schools and the drainage systems, and even more essential than the highway system. Considered in that way, the fare may be regarded as a form of taxation. The problem thus becomes one of taxation, to be dealt with as such, and in a fashion that will produce the best results for the state. If the results desired cannot be secured by continuing the present method of placing the burden entirely upon the riders, "prejudice and conservatism" should not deter us from following a different course. 